\title{
Severe Citrus tristeza virus Isolates from Eastern Mexico Are Related to the T36 Genotype Group
}

\section{Patricia Rivas-Valencia', Santiago Domínguez-Monge ${ }^{2 *}$, Ricardo Santillán-Mendoza ${ }^{2}$, Emiliano Loeza-Kuk³ ${ }^{3}$ Oscar Pérez-Hernández ${ }^{4}$, Cynthia G. Rodríguez-Quibrera² Claudia Lomas-Barrié ${ }^{3}$}

\author{
${ }^{1}$ Instituto Nacional de Investigaciones Forestales, Agrícolas y Pecuarias-Campo Experimental Valle de México, Carretera Los \\ Reyes-Texcoco km 13.5, Coatlinchán, Texcoco, México \\ ${ }^{2}$ Instituto Nacional de Investigaciones Forestales, Agrícolas y Pecuarias-Campo Experimental Ixtacuaco, Carretera Martínez de la \\ Torre-Tlapacoyan km 4.5, Tlapacoyan, Veracruz, México \\ ${ }_{3}^{3}$ Instituto Nacional de Investigaciones Forestales, Agrícolas y Pecuarias-Campo Experimental Mocochá, Carretera Mérida-Motul \\ km 25, Mocochá, Yucatán, México \\ ${ }^{4}$ School of Agricultural Sciences, Northwest Missouri State University, Maryville, USA \\ Email: *dominguez.santiago@inifap.gob.mx
}

How to cite this paper: Rivas-Valencia, P., Domínguez-Monge, S., Santillán-Mendoza, R., Loeza-Kuk, E., Pérez-Hernández, O., Rodríguez-Quibrera, C.G. and Lomas-Barrié, C. (2020) Severe Citrus tristeza virus Isolates from Eastern Mexico Are Related to the T36 Genotype Group. American Journal of Plant Sciences, 11, 1521-1532.

https://doi.org/10.4236/ajps.2020.1110110

Received: August 14, 2020

Accepted: September 27, 2020

Published: September 30, 2020

Copyright (c) 2020 by author(s) and Scientific Research Publishing Inc. This work is licensed under the Creative Commons Attribution International License (CC BY 4.0).

http://creativecommons.org/licenses/by/4.0/ (c) (i) Open Access

\begin{abstract}
Citrus tristeza virus (CTV) outbreaks have been reported in the main citrus growing region of Mexico in the past four years. Recently, in eastern Mexico (the major citrus-growing region in the country), severe CTV isolates have been detected. However, the molecular identity of observed isolates remains unestablished. This research was undertaken to elucidate the molecular characterization of CTV populations spreading in this region and to compare it with phylogeny of existing isolates. Genotyping of 32 collected isolates was performed using reverse-transcription polymerase chain reaction (RT-PCR) with sequence analysis of the coat protein $(\mathrm{CP})$ gene, putatively associated with pathogenicity. This protein is a $25 \mathrm{kDa}$ major capsid protein, which forms a long virion body coating $95 \%$ of the particle length. A comparative sequence analysis was performed using CTV sequences from different geographical origins already published and deposited in the GenBank databases. Phylogenetic analysis showed that the degree of sequence divergence among isolates correlated with their pathogenicity. Based on the sequencing results, the collected isolates were categorized as mild or severe phylogenetic clusters, each being genetically distinct. The severe group was associated with either a-like or with a T36-like genotype. The latter group matched with the quick decline and stem pitting drastic symptoms observed in the field. This study identified the presence of severe CTV isolates related to the T36-like genotype
\end{abstract}


and to the cause of quick decline and stem pitting in sweet orange propagated on sour orange rootstock. Knowledge derived from these analyses could serve to design management strategies for this disease and to understand the current epidemic outbreak in scenarios where the most efficient vector is present.

\section{Keywords}

CTV, Epidemiology, Severe Isolates, Stem Pitting, Quick Decline, Coat Protein Gene

\section{Introduction}

The Citrus tristeza virus (CTV), a member of the genus Closterovirus in the family Closteroviridae, is the causal agent of one of the most destructive viral diseases of citrus and is responsible for the death of over 100 million trees over the last century [1] [2]. The disease is a concern in Mexico, where about 568,188 citrus hectares are grown in 24 states yielding 7.8 million tons of fruit [3]. CTV spread occurs by introduction of infected plants or propagation material, and by several aphid species that transmit the virus semipersistently [4]. The brown citrus aphid [Aphis citricidus Kirkaldy (Syn. Toxoptera citricida)], considered the most efficient vector of CTV [4] [5] [6] [7], entered the country in 2000 through the Yucatan Peninsula and by 2007 it was already in Veracruz, the major citrus-growing region in the country [8].

CTV virions are filamentous particles of about $2000 \times 11 \mathrm{~nm}$, with two coat proteins of $25 \mathrm{kDa}$ (major capsid protein, $\mathrm{CP}$ ) and $27 \mathrm{kDa}$ (minor capsid protein, $\mathrm{CPm}$ ) that cover approximately $95 \%$ and $5 \%$ of the virions, respectively [9] [10]. Its genome is monopartite, composed of a simple RNA chain of $\approx 19.3 \mathrm{~kb}$ and is organized in 12 open reading frames (ORFs) encoding at least 19 proteins [11]. Natural CTV infection occurs as mixtures of genomic variants, which occur in trees exposed to constant re-infestation of aphids [12] [13].

Worldwide, CTV has been reported to infect almost all citrus species, including their hybrids, and can cause various symptoms depending on the virus strain, the host and scion/rootstock combinations [14]. The most common severe symptoms of CTV are: 1) quick decline or death of trees grafted on sour orange (Citrus aurantium L.) rootstock; 2) stem pitting of the scion; and 3) seedling yellows on sour orange, lemon and grapefruit. In the field conditions, strains that not induce visible symptoms on commercial citrus varieties grafted on tolerant rootstock have been considered mild isolates, whereas strains inducing stem pitting, regardless of the rootstock, are considered as severe isolates [1]. CTV isolates are classified into six major genoype groups or strains, namely T3, T30, T36, T68, VT and RB. The classification is based on the nucleotide sequence similarity of the ORF1a [15], which shows levels of sequence identity between CTV variants between $72.3 \%$ and $90.3 \%$.

In Mexico, the presence of severe CTV type variants is indicated in some 
zones of the states of Tamaulipas and Baja California [16]. In these regions, detection of the T30 isolate, widely spreading in the citrus growing areas, has predominated [17] [18] [19] [20] [21]. In Veracruz, the occurrence of CTV structural changes within the spectrum of severe type isolates is reported by other authors [22]. In this region, the epidemiological condition of CTV, defined by the presence of the most efficient vector Aphis citricidus, and the predominance of the most CTV-susceptible rootstock (sour orange) in more than $90 \%$ of the orchards, prompts the need to establish the identity of reported isolates and to study their epidemiological behavior. The objective of this study was to determine and molecular features of CTV isolates spreading in Veracruz using RT-PCR and sequencing of the CP region.

\section{Materials and Methods}

\subsection{Virus Isolates}

Samples from CTV-infected plants were collected between 2016 and 2017 along two transects in northern Veracruz, principal citrus-growing state of Mexico. The sampling was directed at trees with symptoms of decline, stem pitting and branch death. From each tree, young shoots were obtained from the four cardinal points at $1.50 \mathrm{~m}$ from the ground level. The collected material was stored at $4^{\circ} \mathrm{C}$ until processed in the laboratory.

\subsection{RNA Extraction}

Total RNA was extracted using $0.1 \mathrm{~g}$ of mid ribs from CTV infected leaves were ground in $500 \mu \mathrm{L}$ of saline buffer $(\mathrm{NaCl} 1.4 \mathrm{M}$, Tris- $\mathrm{HCl} 0.1 \mathrm{M} \mathrm{pH} \mathrm{8.0)}$ following the protocol by Harris [23]. Subsequently, $600 \mu \mathrm{L}$ of $2 \%$ CTAB, $0.5 \%$ $\beta$-mercaptoethanol in RNase free water was added, mixed by vortexing and incubated at $55^{\circ} \mathrm{C}$ for $30 \mathrm{~min}$. Next, $400 \mu \mathrm{L}$ of phenol: chloroform: isoamyl alcohol (25:24:1) were added, mixed by vortexing and centrifuged at $14000 \mathrm{rpm}$ for 10 $\min$ at $4^{\circ} \mathrm{C}$. From the aqueous phase $500 \mu \mathrm{L}$ were transferred to a new microcentrifuge tube; $1 / 10$ of a volume of ammonium acetate one volume of isoamyl alcohol was added and incubated at $-20^{\circ} \mathrm{C}$ for $10 \mathrm{~min}$. Afterwards, the samples were centrifuged at $14,000 \mathrm{rpm}$ for $5 \mathrm{~min}$, the top layer was discarded and the pellets washed with $1 \mathrm{~mL}$ of $70 \%$ ethanol and centrifuged again at 14,000 rpm for $1 \mathrm{~min}$. After centrifugation, the liquid was discarded and the pellets dried at room temperature before suspending in $30 \mu \mathrm{L}$ of RNases-free water [5]. The quantity and quality of the RNA were determined by spectrophotometry (Thermo Scientific NanoDrop ${ }^{\mathrm{TM}} 2000$ ).

\subsection{Amplification of the CP Genomic Region}

For amplification of the $\mathrm{CP}$ genomic region (672 bp), reverse transcription polymerase chain reaction (RT-PCR) with set of primers IRA1 5'ATGGACGACGAAACAAAGAAATTG3' and IRA2 5'GCTCAACGTGTGTTAA3' [16] was used. To generate the cDNA, approximately $200 \mathrm{ng}$ of total RNA were denatured 
at $95^{\circ} \mathrm{C}$ for $5 \mathrm{~min}$. Afterwards, $1 \mu \mathrm{L}$ of $10 \mu \mathrm{M}$ of each primer were added, along with $1 \mu \mathrm{L}$ of $10 \mathrm{mM} \mathrm{MgCl}_{2}, 0.4 \mu \mathrm{L}$ of $10 \mathrm{mM}$ dNTPs, $0.2 \mu \mathrm{L}$ ( $40 \mathrm{U}$ ) of RNaseOUT (Invitrogen, Carslbad, CA, USA), and $0.2 \mu \mathrm{L}$ (200 U) of M-MLV reverse transcriptase (Promega, Madison, WI), up to a final volume of $6 \mu \mathrm{L}$ and incubated at $42^{\circ} \mathrm{C}$ for $40 \mathrm{~min}$.

The CP genes were amplified by PCR from the cDNA by combining $2 \mu \mathrm{L}$ of cDNA, $2.5 \mu \mathrm{L}$ of 10X Buffer, $1.25 \mu \mathrm{L}$ of $50 \mathrm{mM} \mathrm{MgCl}_{2}, 0.5 \mu \mathrm{L}$ of $10 \mathrm{mM}$ dNTPs, $0.25 \mu \mathrm{L}$ of $10 \mu \mathrm{M}$ each primer, $0.125 \mu \mathrm{L}(1.25 \mathrm{U})$ of Taq DNA Polymerase (Promega, Madison, WI) and RNase-free water to a final volume of $25 \mu \mathrm{L}$. The amplification was carried out in a T100 thermocycler (BioRad, Hercules, CA) and consisted from 1 cycle at $95^{\circ} \mathrm{C}$ for $1 \mathrm{~min}, 35$ cycles of $1 \mathrm{~min}$ at $94^{\circ} \mathrm{C}, 1 \mathrm{~min} 55^{\circ} \mathrm{C}$, and $1 \mathrm{~min}$ at $72^{\circ} \mathrm{C}$ followed by a period of final extension of $5 \mathrm{~min}$ at $72^{\circ} \mathrm{C}$.

\subsection{Sequencing and Phylogenetic Analysis}

PCR products were resolved in $1 \%$ agarose gels, then were purified utilizing a commercial kit, and sequenced by an external company (Macrogen, Seoul, Korea). DNA Sequences were manually edited using PreGap and Gap [24] to obtain consensus sequences.

The consensus sequences were aligned and manually edited using MUSCLE [25]. The sequences were analyzed with maximum parsimony (MP) (PAUP4.0a167) [26] and Bayesian Inference (BI) (MrBayes v.3.2) [27] to infer phylogenies. MP analysis was carried out utilizing 1000 random-sequence-addition replicates and tree-bisection and reconnection (TBR) with branch swapping, excluding gaps and non-informative characters, leaving a total of 586 positions in the final matrix. Nodes support was determined for bootstrap values with 1000 replicates. BI analysis was performed with ten million generations, where four MCMCs (Markov Chain Monte Carlo) were run simultaneously. The branch lengths were calculated as the average rates of change at each branch of the largest posterior probability trees. Phylogenetic trees were visualized and edited using Mesquite v3.61 [28].

Accession numbers for previously reported CTV nucleotide sequences used in this study were: T36 (U166034), T30 (AF260651), VT (U56902), T385 (Y18420), SY568 (AF001623), NUagA (AB011185), CTV (DQ272579), NZ-M16 (EU857538), NZ-B18 (FJ525436), TAM11 (AF342890 and AY652895), NL8 (AF342891 and AY652892), VER2-2 (AF342892), QR2753-1 (AF342893 and AY652893), BC15-1 (AF342894 and AY652899) MichL9A11/9-1 (AF342895), Colima 1997 (AY649491) y Yucatán 2000 (AY649492).

\section{Results}

\subsection{Symptoms of Severe CTV in Sweet Orange Trees}

Typical CTV symptoms on sweet orange trees were observed in all trees sampled in the study. The severe symptoms of CTV isolates were identified only on sour orange rootstock. These symptoms varied from a vein clearing, death of branches, stem pitting of the scion that reduces yield and fruit quality to a gradual tree de- 
clining (Figures 1(A)-(D)).

\subsection{Phylogeny of CTV Isolates}

In total, a dataset of 586 nucleotides of the CP region of the CTV genome were determined. Alignments of this genomic region indicated that variations at nucleotide level were simple nucleotide changes. Overall similarities for the CP region among CTV Mexican isolates ranged from $86.7 \%$ to $99.8 \%$ at the nucleotide level (78 and 1 nucleotides, respectively). However, the sequences of these strains clustered into two groups that had very high sequences homology $(99.8 \%$ identical nucleotides, only one transition $\mathrm{T} \times \mathrm{C}$ ) such as Mx-Ver1 and Mx-Ver2 and less sequences homology (91\% identical nucleotides) such as $\mathrm{Mx}$-VerC7, Mx-VerL1A5 and Mx-Ver3 (data not shown).

The maximum parsimony and Bayesian inference method were used to generate the phylogenetic tree for the $\mathrm{CP}$ region including the following full length CTV sequences: T36 [11] and T30 from Florida [29], VT from Israel [30], T385 from Spain [31], SY568 from California [32], NUagA from Japan [33], CTV from Mexico [34], NZ-M16 and NZ-B18 from New Zealand [35]; and CP sequences from Mexico: TAM11, NL8, VER2-2, QR2753-1, BC15-1, MichL9A11/9-1, Colima 1997 and Yucatán 2000 [16].

In the phylogenetic tree a very consistent and defined cluster was observed with a bootstrapping over 99, which included the highly homologous Mexican isolates (Mx-Ver1 and Mx-Ver2) as well as isolates T30, Yucatán 2000, Colima 1997, MichL9A11/9-1, QR2753-1, VER2-2, NL8 and T385 (Figure 2).
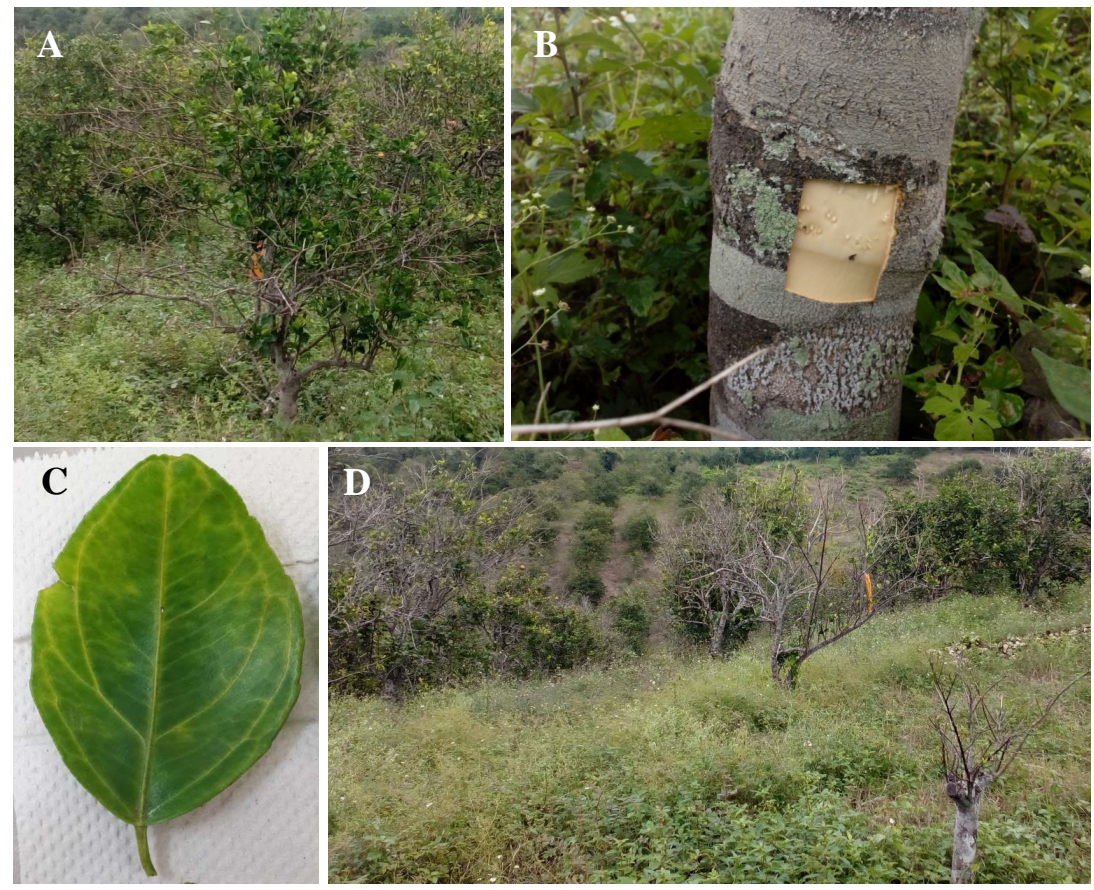

Figure 1. Symptoms of severe CTV in sweet orange (Citrus sinensis). (A) Death of branches; (B) Stem pitting; (C) vein clearing; (D) Quick decline. In each scenario, CTV presence was confirmed as positive by RT-PCR and was related to the T36-like genotype. 


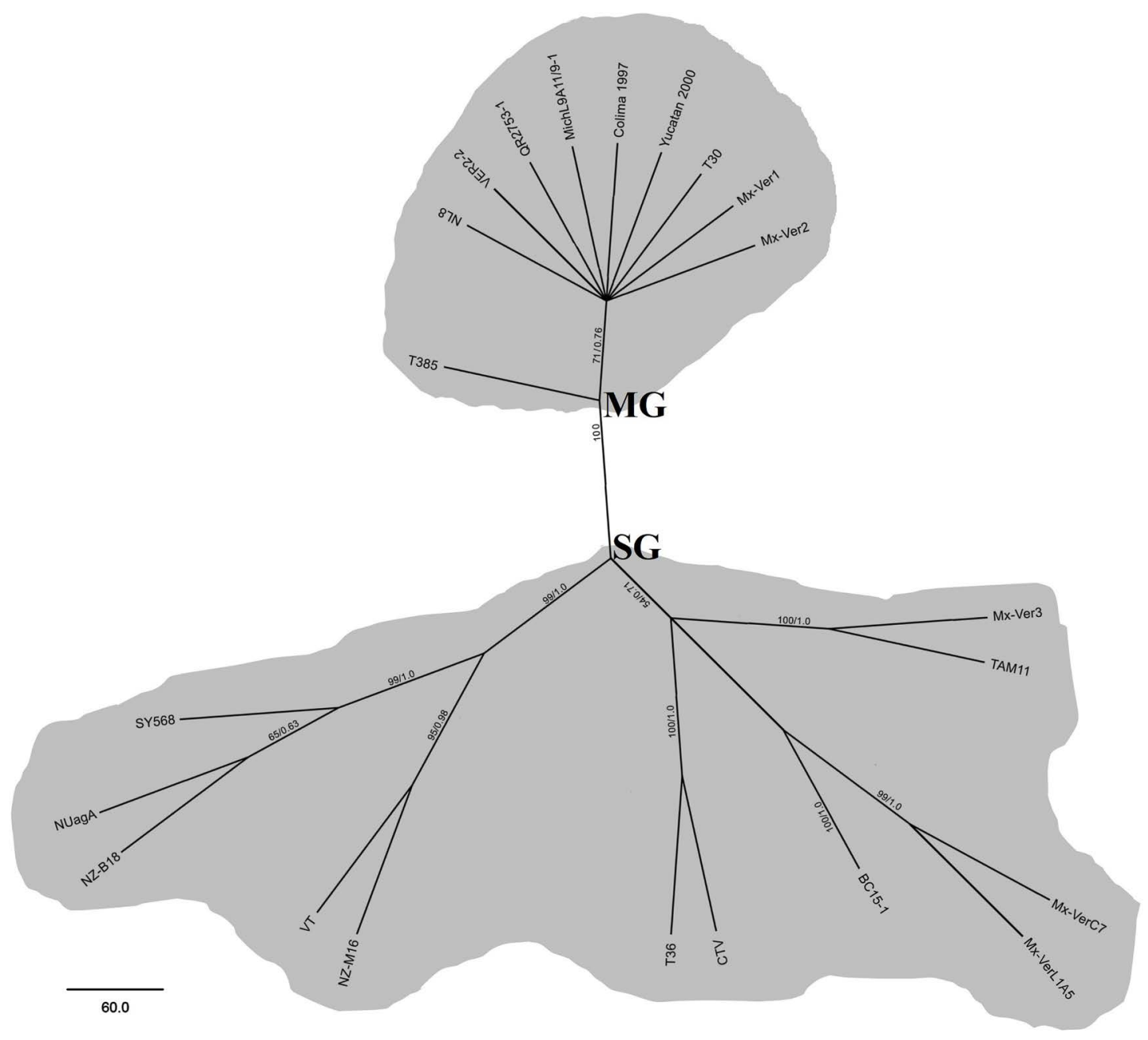

Figure 2. Maximum Parsimony analysis (MP) of Citrus tristeza virus using coat protein (CP) gene sequences. Phylogenetic tree was generated using PAUP as indicated in Materials and Methods. A similar topology was generated using Bayesian inference (BI) with MrBayes. Only one of the seven most parsimonious trees (length = 171 ) is shown. The consistency and retention indices were 0.7572 and 0.9000 , respectively, while the homoplasy index was 0.2428 . Bootstrap support values $(>60 \%)$ based on 1000 replicates and Bayesian posterior probabilities $(>0.6)$ based on ten million generations are indicated at the internodes in the order MP/BI.

On the other hand, CTV isolates Mex-Ver3, Mex-VerC7, Mx-VerL1A5, NUagA, VT, SY568, NZ-B18, NZ-M16, TAM11, BC15-1, CTV and T36, which induce severe symptoms, showed a more disperse phylogenetic distribution (Figure 2). The comparative analysis revealed that the severe Mexican isolates Mex-Ver3, Mex-Ver7 and Mx-VerL1A5, tended to be clustered away from the group formed by SY568, NUagA, NZ-B18, VT and NZ-M16, although not enough to be considered a separate cluster.

\section{Discussion}

The focus of this study was to characterize the molecular profile of CTV isolates from the northern region of Veracruz, Mexico and to examine their phylogenetic relationships with reported CTV isolates. The epidemic outbreak of severe 
CTV symptoms in sweet orange in northern Veracruz, where around $90 \%$ of the orchards are established with the combination of sweet orange/sour orange susceptible to the disease, is a real and worrisome situation that has epidemiological implications, particularly if CTV isolates are differentially transmitted by aphids [36] [37] [38]. The main vector (Aphis citricidus) has been present in Veracruz since 2007 [8], so our hypothesis is that the vector may be selecting and spreading severe isolates, that already exist in the pool of regional isolates [5] [39].

The phylogenetic relationships among different CTV isolates from Mexico, analyzed by sequencing of the $\mathrm{CP}$ genomic region, also allowed comparison of Mexican isolates with those reported in the GenBank database.

To establish the degree of homogeneity in the virus population, the sequences alignments of the Mexican isolates were compared with isolates of the six distinct genotypes and whose complete genome sequences are known: a severe quick decline isolate T36 from Florida-USA [11], grapefruit stem pitting and a decline isolate VT from Israel [30], a sweet orange stem pitting and seedling yellow isolate SY568 from California-USA [32], a seedling yellow isolate NUagA from Japan [33], a quick decline and stem pitting isolate CTV from Mexico [34], a mild stem pitting isolate in sweet orange NZ-M16 from New Zealand [35], a severe stem pitting and seedling yellows isolate NZ-B18 from New Zealand [35], a severe vein cleaning, severe stem pitting and quick decline isolate TAM11 from Mexico, a severe vein cleaning and moderate stem pitting in Mexican lime isolate BC15-1 from Mexico [16] and eight mild isolates, T385 from Spain, T30 from Florida-USA [24] and NL8, VER2-2, QR2753-1,, MichL9A11/9-1, Colima 1997 and Yucatán 2000 from Mexico [16].

The results of the present study showed that clustering of isolates highly correlates with their symptom severity. The overall branching pattern of the phylogenetic tree was highly similar for all the mild isolates, including two of the Mexican isolates, forming a single cluster. This high similarity is not surprising since the mild isolate T30 from Florida, is widely distributed in the citrus areas of Mexico [18] [40]. However, a different situation was observed for the severe isolates, where a unique branch could not be identified for them. In this way, the severe isolates were located more dispersed in the tree and grouped with the severe isolate T36 from Florida, which causes vein cleaning, severe stem pitting and declining.

Our results are in agreement with several reports that suggest a considerable degree of sequence variation in CTV isolates. The sequencing of the $\mathrm{CP}$ region from seven CTV isolates from Florida, allowed their classification into three groups, I (severe-like T36), II (severe-like T3) and III (mild) represented by sequences of T36, T3 and T30, respectively, with discernible differences at the nucleotide level among the CTV isolates. This grouping was confirmed by adding an additional four virus isolates from several countries since all sequences could be assigned to one of the three types previously established [41].

Another report compared the predominant sequence variants of $\mathrm{CP}$ gene from eight CTV isolates of different geographic origin and pathogenicity [16]. 
As a result of the phylogenetic analyses, the CTV isolates were separated in two groups: first (mild group) including the mild isolates and second (severe group) including the severe isolates. This last group was loosely more disperse but included all symptomatic isolates, maybe as result of recombination events [42]. When we compared the five Mexican isolates with those eight reported for CP [16], the divergence among the CTV isolates was similar forming two clearly distinct groups: mild and severe. Although the data presented in this work are based on a limited number of CTV isolates from northern Veracruz, they clearly indicated the existence of a severe-like T36 genotype associated to the symptoms commonly occurring in this region.

\section{Summary}

In summary, this study is the first attempt to the molecular characterization of CTV isolates from reports of severe symptoms of CTV in Veracruz by the official sector of Mexico [43]. The study established that severe isolates of CTV observed in that region are related to the T36 genotype group, both molecularly and by symptomology. The findings suggest the need for determining the population structure of CTV in other citrus-growing regions of the Gulf of Mexico and the Yucatan Peninsula. In the latter region, in particular, such a need should be a priority due to the historical presence of Aphis citricidus, putatively the most important vector of CTV, and due to the disease status in terms of economic importance to the state. Information from the analysis reported herein could be useful to design management strategies for CTV and to understand the current epidemic outbreak under scenarios where the effective aphid vector is present.

\section{Conflicts of Interest}

The authors declare no conflicts of interest regarding the publication of this paper.

\section{References}

[1] Bar-Joseph, M., Batuman, O. and Roistacher, C.N. (2010) The History of Citrus tristeza virus-Revisited. In: Karasev, A.V. and Hilf, M.E., Eds., Citrus tristeza virus Complex and Tristeza Diseases, APS Press, St. Paul, 3-26.

[2] Moreno, P., Ambros, S., Albiachi-Marti, M.R., Guerri, J. and Peña, L. (2008) Citrus tristeza vírus: A Pathogen That Changed the Course of the Citrus Industry. Molecular Plant Pathology, 9, 251-268. https://doi.org/10.1111/j.1364-3703.2007.00455.x

[3] SIAP (2019) Servicio de Información Agroalimentaria y Pesquera. Consultado online el 10 de abril de 2020 .

http://infosiap.siap.gob.mx:8080/agricola siap gobmx/AvanceNacionalSinProgram a.do

[4] Gottwald, T.R., Garnsey, S.M., Cambra, M., Moreno, P., Irey, M. and Borbon, J. (1997) Comparative Effects of Aphid Vector Species on Increase and Spread of $\mathrm{Ci}$ trus tristeza virus. Fruits, 52, 397-404.

[5] Loeza-Kuk, E., Ochoa-Martínez, D., Mora-Aguilera, G., Rivas-Valencia, P., Gu- 
tiérrez-Espinosa A., Cintra de Jesús Junior, W., Villegas-Monter, A. and Arno Wulff, N. (2008) Acquisition of CSDAV and Haplotypes of Citrus tristeza virus by Toxopetera citricida and Aphis spiraecola and the Implication on Citrus Sudden Death. Agrociencia, 42, 669-678.

[6] Hermoso de Mendoza, A., Ballester-Olmos, J.F. and Pina, L.J.A. (1984) Transmission of Citrus tristeza virus by Aphids (Homoptera, Aphididae) in Spain. International Organization of Citrus Virologists Conference Proceedings (1957-2010), 9, 23-27. https://escholarship.org/uc/item/5zj9877d

[7] Raccah, H.B., Loebenstein, G. and Singer, S. (1980) Aphid Transmissibility Variants of Citrus tristeza virus in Infected Citrus Trees. Phytopathology, 70, 89-93. https://doi.org/10.1094/Phyto-70-89

[8] López-Arroyo, J.I., Loera-Gallardo, J., Rocha-Peña, M.A., Canales, R., Hernández, I., Reyes, M.A., Berlanga, A. and Miranda, M.A. (2008) Pulgón café de los cítricos, Toxoptera citricida (Hemíptera: Aphididdae). In: Arredondo, H.C. and Rodríguez, L.A., Eds., Casos de control biológico en México, Grupo Mundi-Prensa, México, 279-292.

[9] Febres, V.J., Ashoulin, L., Mawassi, M., Frank, A., Bar-Joseph, M., Manjunath, K.L., Lee, R.F. and Niblett, C.L. (1996) The p27 Protein Is Present at One End of Citrus tristeza virus Particles. Phytopathology, 86, 1331-1335.

[10] Satyanarayana, T., Gowda, S., Ayllón, M.A. and Dawson, W.O. (2004) Closterovirus Bipolar Virion: Evidence for Initiation of Assembly by Minor Coat Protein and Its Restriction to the Genomic RNA 5' Region. Proceedings of the National Academy of Sciences of the United States of America, 101, 799-804. https://doi.org/10.1073/pnas.0307747100

[11] Karasev, A.V., Boyko, V.P., Gowda, S., Nikolaeva, O.V., Hulf, M.E., Koonim, E.V., Niblett, C.L., Cline, K., Gumph, D.J., Lee, R.F., Garnsey, S.M., Lewandowski, D.J. and Dawson, W.O. (1995) Complete Sequence of the Citrus tristeza virus RNA Genome. Virology, 208, 511-520. https://doi.org/10.1006/viro.1995.1182

[12] Moreno, P., Guerri, J., Ballester-Olmos, J.F., Albiach, R. and Martínez, M.E. (1993) Separation and Interference of Strains from a Citrus tristeza virus Isolate Evidenced by Biological Activity and Double-Stranded RNA (dsRNA) Analysis. Plant Pathology, 42, 35-41. https://doi.org/10.1111/j.1365-3059.1993.tb01469.x

[13] Powell, C.A., Pelosi, R.R. and Cohen, M. (1992) Superinfection of Orange Trees Containing Mild Isolates of Citrus tristeza virus with Severe Florida Isolates of $\mathrm{Ci}^{-}$ trus tristeza virus. Plant Disease, 76, 141-144. https://doi.org/10.1094/PD-76-0141

[14] Roistacher, C.N. and Moreno, P. (1991) The Worldwide Threat from Destructive Isolates of Citrus tristeza virus a Review. Proceedings 11 th Conference International Organization of Citrus Virologists, IOCV, Riverside, 7-19.

[15] Harper, S.J. (2013) Citrus tristeza virus: Evolution of Complex and Varied Genotypic Groups. Frontiers in Microbiology, 4, 93.

https://doi.org/10.3389/fmicb.2013.00093

[16] Herrera-Isidrón, L., Ochoa-Sánchez, J.C., Rivera-Bustamante, R. and Martínez-Soriano, J.P. (2009) Sequence Diversity on Four ORFs of Citrus tristeza virus Correlates with Pathogenicity. Virology Journal, 6, Article No. 116. https://doi.org/10.1186/1743-422X-6-116

[17] Rivas-Valencia, P., Loeza-Kuk, E., Domínguez-Monge, S. and Lomas-Barrié, C.T. (2017) Chronic Infection of the Citrus tristeza virus in Citrus sinensis/C. aurantium Trees in a Restrictive Thermal Regime in Yucatán. Revista Chapingo Serie Horticultura, 23, 187-202. https://doi.org/10.5154/r.rchsh.2016.11.028 
[18] Domínguez-Monge, S., Mora-Aguilera, G., Loeza-Kuk, E., Gutiérrez-Espinosa, M.A., Flores-Sánchez, J., Acevedo-Sánchez, G., Ochoa-Martinez, D., Febres, V., Hernández-Nava, G. and Martínez-Bustamante, V. (2014) Epidemiología molecular de aislamientos de citrus tristeza virus de la Península de Yucatán. Revista Mexicana de Fitopatología, 32, 46.

[19] Domínguez-Monge, S., Mora-Aguilera, G., Loeza-Kuk, E., Rivas-Valencia, P., Ruiz-García, N., Días-Padilla, G., Acevedo-Sánchez, G., Munguía-Rosales, R., Velázquez-Toledo, J., Escalante-Márquez, F. and Robles-García, P. (2010) Regionalización epidemiológica de la tristeza de los cítricos en la Península de Yucatán. $V$ Reunión Nacional de Innovación Agrícola, Campeche, 22-27 noviembre 2010, 334.

[20] Rivas, V.P., Loeza, K.E., Mora-Aguilera, G., Ruiz, G.N., Ochoa, M.D., Gutiérrez, E.A. and Febres, V. (2010) Análisis Espacio-Temporal de aislamientos del Citrus tristeza virus de Yucatán y Tamaulipas. Revista Mexicana de Ciencias Agrícolas, 1, 493-507.

[21] Loeza-Kuk, E., Palacios-Torres, E.C., Ochoa-Martínez, D., Mora-Aguilera, G., Gutiérrez-Espinosa, M.A., Febres, V.J., Moore, G.A. and Alvarez-Ramos, R. (2005) Molecular Characterization of Citrus tristeza virus Isolates from Veracruz and Tamaulipas States, México. In: Hilf, M.E., Duran-Vila, A. and Rocha-Peña, M.A., Eds., Proceedings 16th IOCV Conference, International Organization of Citrus Virologists and University of California, Riverside, CA, USA, 407-411.

https://www.researchgate.net/publication/267417106 Molecular Characterization of Citrus tristeza virus Isolates from Veracruz and Tamaulipas States Mexico

[22] López-Vera, E.E., Domínguez-Monge, S., Santillán-Mendoza, R., Rodríguez-Quibrera, C. and Martínez-Rivera, N. (2019) Ocurrencia de aislamientos severos del Citrus tristeza virus en árboles de naranja dulce en Veracruz. XXXII Reunión CientíficaTecnológica, Forestal y Agropecuaria y IV Congreso Mexicano de Investigación en Cítricos, World Trade Center, Boca del Río, Veracruz, 14 y 15 de Noviembre, 529-534.

[23] Harris, A. (2002) Nepoviruses and Their Diagnosis in Plants: A Novel Polymerase Chain Reaction Diagnostic Test for Nepoviruses in Nursery Stock. Biosecurity Australia, Biosecurity Australia

[24] Bonfield, J.K. and Whitwham, A. (2010) Gap5-Editing the Billion Fragment Sequence Assembly. Bioinformatics. 26, 1699-1703.

https://doi.org/10.1093/bioinformatics/btq268

[25] Edgar, R.C. (2004) MUSCLE: Multiple Sequence Alignment with High Accuracy and High Throughput. Nucleic Acids Research, 32, 1792-1797.

https://doi.org/10.1093/nar/gkh340

[26] Swofford, D.L. (2002) PAUP*. Phylogenetic Analysis Using Parsimony (*and Other Methods). Version 4.0 a 167. Sinauer Associates, Sunderland, MA.

[27] Ronquist, F., Teslenko, M., Van der Mark P., Ayres, D.L., Darling, A., Höhna, S., Larget, B., Liu, L., Suchard, M.A. and Huelsenbeck, J.P. (2012) MrBayes 3.2: Efficient Bayesian phylogenetic Inference and Model Choice across a Large Model Space. Systematic Biology, 61, 539-542. https://doi.org/10.1093/sysbio/sys029

[28] Maddison, W.P. and Maddison, D.R. (2019) Mesquite: A Modular System for Evolutionary Analysis. Version 3.61. http://mesquiteproject.org

[29] Albiach-Marti, M.R., Mawassi, M., Gowda, S., Satyanarayana, T., Hilf, M.E., Shanker, S., Almira, E.C., Vives, M.C., Lopez, C., Guerri, J., Flores, R., Moreno, P., Garnsey, S.M. and Dawson, W.O. (2000) Sequences of Citrus tristeza virus Separated in Time and Space Are Essentially Identical. Journal of Virology, 74, 6856-6865. 
https://doi.org/10.1128/JVI.74.15.6856-6865.2000

[30] Mawassi, M., Mietkiewska, E., Gofman, R., Yang, G. and Bar-Joseph, M. (1996) Unusual Sequence Relationships between Two Isolates of Citrus tristeza virus. Journal of General Virology, 77, 2359-2364. https://doi.org/10.1099/0022-1317-77-9-2359

[31] Vives, M.C., Rubio, L., Lopez, C., Navas-Castillo, J., Albiach-Marti, M.R., Dawson, W.O., Guerri, J., Flores, R. and Moreno, P. (1999) The Complete Genome Sequence of the Major Component of a Mild Citrus tristeza virus Isolate. Journal of General Virology, 80, 811-816. https://doi.org/10.1099/0022-1317-80-3-811

[32] Yang, Z.N., Mathews, D.M., Dodds, J.A. and Mirkov, T.E. (1999) Molecular Characterization of an Isolate of Citrus tristeza virus That Causes Severe Symptoms in Sweet Orange. Virus Genes, 19, 131-142. https://doi.org/10.1023/A:1008127224147

[33] Suastika, G., Natsuaki, T., Terui, H., Kano, T.H.I. and Okuda, S. (2001) Nucleotide Sequence of Citrus tristeza virus Seedling Yellows Isolates. Journal of General Plant Pathology, 67, 73-77. https://doi.org/10.1007/PL00012992

[34] Quiroz, V.J.C., Peña del Rio, M.A., Cruz, H.A., Fernández, D.S., González, P.M. and Mendoza, H.A. (2008) Secuencia del genoma de un aislamiento del virus de la tristeza de los cítricos. Revista Fitotecnia Mexicana, 31, 95-104.

[35] Harper, S.J., Dawson, T.E. and Pearson, M.N. (2009) Complete Genome Sequences of Two Distinct and Diverse Citrus tristeza virus Isolates from New Zealand. Archives of Virology, 154, 1505-1510. https://doi.org/10.1007/s00705-009-0456-Z

[36] Domínguez-Monge, S., Mora-Aguilera, G., Loeza-Kuk, E., Flores-Sánchez, J., Acevedo-Sánchez, G. and Robles-García, P. (2012) Implication of Toxoptera citricida on Temporal and Spatial Dispersion the Citrus tristeza virus in Southern Mexico. 12 th International Citrus Congress, 18th-23rd November 2012, 240.

[37] Broadbent, P., Brlansky, R.H. and Indsto, J. (1996) Biological Characterization of Australian Isolates of Citrus tristeza virus and Separation of Subisolates by Single Aphid Transmissions. Plant Disease, 80, 329-333.

https://doi.org/10.1094/PD-80-0329

[38] Ballester-Olmos, J.F., Pina, J.A., Carbonell, E.A., Moreno, P., Hermoso de Mendoza, A., Cambra, M. and Navarro, L. (1993) Biological Diversity of Citrus tristeza virus (CTV) Isolates in Spain. Plant Pathology, 42, 219-229. https://doi.org/10.1111/j.1365-3059.1993.tb01494.x

[39] Yokomi, R., Lastra, R., Stoetzel, M.B., Damsteegt, V.D., Lee, R.F., Garnsey, S.M., Gottwald, T.R., Rocha-Peña, M.A. and Niblett, C.L. (1994) Establishment of the Brown Citrus Aphid (Homoptera: Aphididae) in Central America and the Caribbean basin and Transmission of Citrus tristeza virus. Journal of Economic Entomology, 87, 1078-1085. https://doi.org/10.1093/jee/87.4.1078

[40] Rivas-Valencia, P., Loeza-Kuk, E., Domínguez-Monge, S. and Mora-Aguilera, G. (2015) Prevalencia de aislamientos tipo T-30 del Citrus Tristeza Virus (CTV) en Yucatán, México. Revista Mexicana de Fitopatología, 33, 230.

[41] Pappu, H., Pappu, S., Niblett, C., Lee, R. and Civerolo, E. (1993) nComparative Sequence Analysis of the Coat Proteins of Biologically Distinct Citrus tristeza closterovirus Isolates. Virus Genes, 7, 255-264.

https://doi.org/10.1007/BF01702586

[42] Sambade, A., Lopez, C., Rubio, L., Flores, R., Guerri, J. and Moreno, P. (2003) Polymorphism of a Specific Region in Gene p23 of Citrus tristeza virus Allows Discrimination between Mild and Severe Isolates. Archives of Virology, 148, 2325-2340. 
https://doi.org/10.1007/s00705-003-0191-9

[43] SENASICA (2020) Plagas Reglamentadas de los Cítricos. Virus de la tristeza de los cítricos-Severo. Servicio Nacional de Sanidad, Inocuidad y Calidad AgroalimentariaDirección General de Sanidad Vegetal.

http://sinavef.senasica.gob.mx/MDF/ 